\title{
An Empirical Study of E-Marketplace Acceptance by MSMEs in Bali using TOE Model
}

\author{
Nyoman Sri Subawa \\ Faculty of Economic and Business, \\ Universitas Pendidikan Nasional \\ Jl. Bedugul No. 39 \\ Sidakarya, Denpasar, Indonesia \\ shribawa@undiknas.ac.id
}

\author{
Caren Angellina Mimaki \\ Faculty of Economic and Business, \\ Universitas Pendidikan Nasional \\ Jl. Bedugul No. 39 \\ Sidakarya, Denpasar, Indonesia
}

\begin{abstract}
In the world today, undoubtedly e-commerce has proven to be beneficial and convenient to both merchants (seller) and consumers (buyer) particularly with various e-marketplace platforms such as Lazada, Shoppe, e-bay and many more. However, not many entrepreneurs took up the opportunity and ventured into emarketplace. This scenario is more noticeable among the MSMEs entrepreneurs in developing countries. Hence, this study aimed to fill the gap and provide richer insights in technology acceptance from the user, environment, technology, and organizational side by applying the Technological, Organizational, and Environmental (TOE) framework model. This research was conducted in three regencies of Bali (Denpasar, Badung and Gianyar) by distributing five-point Likert scale questionnaires to 100 entrepreneurs (who meet the criteria). The developed hypotheses testing analysis was based on Partial Least Square Structural Equation Model (PLSSEM) and was conducted using SmartPLS 3.0. Findings obtained revealed that organizational $(\mathrm{p}=0.042$, and $\mathrm{t}$-statistics $=2.062)$ and environmental factors $(\mathrm{p}=0.011$ and t-statistics $=2.587)$ had positive significance towards behavioral intention (BI) in accepting e-marketplace.
\end{abstract}

\section{CCS CONCEPTS}

-Information systems $\sim$ Enterprise applications $\sim$ Information systems $\sim$ E-commerce infrastructure

\section{KEYWORDS}

e-marketplace, MSMEs, TOE, Indonesia, acceptance

\section{ACM Reference format:}

Nyoman Sri Subawa, Caren Angellina Mimaki. 2019. An Empirical Study of E-Marketplace Acceptance by MSMEs in Bali using TOE Model. In Proceedings of 2019 International Conference on E-Business, Information Management and Computer Science (EBIMCS2019). December, 2019, Kuala Lumpur, Malaysia. ACM, New York, NY, USA. 5 pages. https://doi.org/10.1145/3377817.3377837

\footnotetext{
*Article Title Footnote needs to be captured as Title Note

Author Footnote to be captured as Author Note

Permission to make digital or hard copies of part or all of this work for personal or classroom use is granted without fee provided that copies are not made or distributed for profit or commercial advantage and that copies bear this notice and the full citation on the first page. Copyrights for third-party components of this work must be honored. For all other uses, contact the owner/author(s). EBIMCS2019, December, 2019, Kuala Lumpur, Malaysia (C) 2019 Copyright held by the owner/author(s). 978-1-4503-6649-6/19/12..\$15.00 https://doi.org/10.1145/3377817.3377837
}

\section{INTRODUCTION}

With the advancement of information communication and technology (ICT), internet is one of the biggest inventions of mankind as it enable human to connect globally regardless of time. Information are also shared and received at ease with the help of internet. One of the sectors which benefited from this is the economic field, namely business and commerce.

One of the applications of information technology and the internet in the field of business and commerce is the electronic marketplace (e-marketplace). E-marketplace can be defined as a market that utilizes digital media such as the internet to create an environment or place that accommodates sellers and buyers to conduct various businesses. Electronic Marketplace has a concept similar to traditional markets, which is where buyers and sellers meet. However, the difference between e-marketplaces and traditional markets is that e- marketplaces are more computerized by using network assistance to support markets so that it can be done efficiently in providing updated information and services to different sellers and buyers. Although e-marketplace has a lot offer, yet it is still not widely accepted by many MSMEs [1].

Technological factors, organizational and environmental factors are also important aspects that can influence a person to adopt or not adopt a system Technology-Organization-Environment (TOE) Framework is a theory developed by Tornatzky and Fleischer in 1990 which is a comprehensive tool for studying the adoption of technology in an organization that identifies three aspects of an organization that influence the adoption of new technology [2]. Technology context explains about both internal and external technologies that relevant to the firm, organizational context refers to descriptive measures about the organization, while environmental context describes the arena in which a firm conducts its business. The existence of infrastructure and ICT capability, financial resources, top management support, and external factors including market forces and government e-readiness are crucial factors that can influence the interests of entrepreneurs in adopting the system. TOE framework also has been widely used in various technology adoption researches such as exploring the adoption of ERP solution by SMEs [3], identify effective factors on RFID adoption in supply chain management of manufacturing industries in SMEs [4], explain the critical determinants for the adoption of emarket in Australian SMEs [2], and this model also can be combined with other models including TAM to understand the determinants of cloud computing adoption [5].In a study done in Tanzania, Kabanda and Brown[6] reported that SMEs use websites 
in a limited way, as they draw upon their understanding of websites as being incompatible with the Tanzanian cultural bargaining system, which is characterized by cash transactions and face to face bargaining. Nevertheless, the use mobile technology is extensive due to the devices' ability to offer transactive capability, mobility, and communication. In the aspect of environmental factors, the SMEs faced obstacles such as lack of supporting industry and institutional support. Abdullah[7] researched on the e-business adoption by SMEs in Yemen and found that cost of accessing internet and ICT infrastructure are high causing SMEs not to adopt email, social media, a website, or even e-business. Besides, in the context of organizational readiness, results indicated that most of the employees have limited access to a computer and most of them are computer/internet illiterate. As for governmental readiness, there are interruptions in electric power and poor internet connectivity. Furthermore, SMEs are unaware if a telecommunications regulatory authority exists, and whether policies exist to protect all entities against fraud. Lastly, there is lack of communication between banks and SMEs with regards to the implementation of new technologies by the banking sector that could support SMEs in adopting advanced technologies, and supporting their technology strategy.

Therefore, this study applied TOE framework model in determining the e-marketplace acceptance of MSMEs in Gianyar, Denpasar and Badung by 100 entrepreneurs. Three hypotheses as follow are proposed and evaluated in this study:

H1: Technological factor has a positive relationship towards behavior intention in utilizing e-marketplace.

$\mathrm{H} 2$ : Organizational factor has a positive relationship towards behavior intention in utilizing e-marketplace

H3: Environmental factor has a positive relationship towards behavior intention in utilizing e-marketplace.

\section{METHODOLOGY}

\subsection{Research Location}

The three economically blooming regencies of Bali which are Denpasar, Badung and Gianyar are the targeted locations of this study. With reference to the economic report in August 2019, Badung and Denpasar held the top position of 35,248 and 34,168 in 2018. On the other hand, Gianyar had the highest number of MSMEs in the Bali Province with 75,412 units.

\subsection{Research Population and Sample}

Since this research is aimed at analyzing the adoption of emarketplace of MSMEs in Bali, the population of this study is the MSMEs in the nine regencies in Bali itself. From these regencies, the study is narrowed down to three specific regencies which are Gianyar, Denpasar and Badung. The MSMEs in these three regencies are the samples selected. Despite that, the MSMEs need to meet the main criterion of this study which is, the MSMEs entrepreneurs have to be e-marketplace users.

In order to determine the sample size of each regency, cluster sampling technique is used. Partial Least Square Structural Equation Model (PLS-SEM) helped in estimating the number of
MSMEs samples as shown in Table 1 for a given 100 sample respondents.

Table 1. Cluster sampling calculation

\begin{tabular}{|c|c|c|c|}
\hline Regency & $\begin{array}{c}\text { Number of } \\
\text { population } \\
\text { in 2018 } \\
\text { (thousand) }\end{array}$ & $\begin{array}{c}\text { Cluster } \\
\text { sampling }\end{array}$ & $\begin{array}{c}\text { Number of } \\
\text { samples } \\
\text { (approximately) }\end{array}$ \\
\hline Badung & 930.60 & $\frac{930.60}{2095.6} \times 100$ & 45 \\
\hline Denpasar & 656.90 & $\frac{656.90}{2095.6} \times 100$ & 31 \\
\hline Gianyar & 508.10 & $\frac{508.10}{2095.6} \times 100$ & 24 \\
\hline Total & 2095.6 & & 100 \\
\hline
\end{tabular}

\subsection{Data Collection and Analysis}

The quantitative data in this study were collected using a 5-point Likert scale questionnaire that was prepared in English but also translated into Bahasa to ease the respondents in answering. The scales ranged from 5 "strongly agree" to 1 "strongly disagree". These questionnaires were distributed to the MSMEs of each regency as sampled in Table 1 . The questionnaire in this study included statements and each respondent was asked to give an assessment in accordance with the instructions in the questionnaire. The questionnaire consists of several parts, namely the part that shows the identity of the respondent, the filling instructions section, and the last section which contains a number of structured statements about the research constructs.

Data collection is carried out for two weeks and distributed directly to the MSMEs. After these two weeks, the number of respondents who answered the questionnaire was 112 MSMEs. Although 112 questionnaires were returned, not all of it was usable since some were incomplete. Upon filtering the questionnaire, 8 were incomplete and 4 were eliminated, leaving only 100 questionnaires that meet the requirements and deserve to be processed.

The data were descriptively evaluated using version 25 of IBM SPSS software while the hypotheses were tested using SmartPLS 3.0 software. Prior to hypotheses testing, the questionnaire was validated.

\subsection{Operational Variable Definitions}

The definition for each of the variables used in this study is explained as in Table 2.

Table 2. Operational Variable Definitions [2,5, 8-11]

\begin{tabular}{|c|c|}
\hline $\begin{array}{c}\text { Variable and } \\
\text { Definition }\end{array}$ & Indicators \\
\hline $\begin{array}{l}\text { Technological } \\
\text { Factors } \\
\text { (TECH) :Technological } \\
\text { context refers to both } \\
\text { internal and external } \\
\text { technologies used by }\end{array}$ & $\begin{array}{l}\text { ICT Infrastructure } \\
\text { - Our firm uses information, } \\
\text { communication and } \\
\text { networking technology } \\
\text { We have the necessary } \\
\text { technical, managerial and other }\end{array}$ \\
\hline
\end{tabular}


An Empirical Study of E-Marketplace Acceptance by MSMEs in Bali using TOE Model

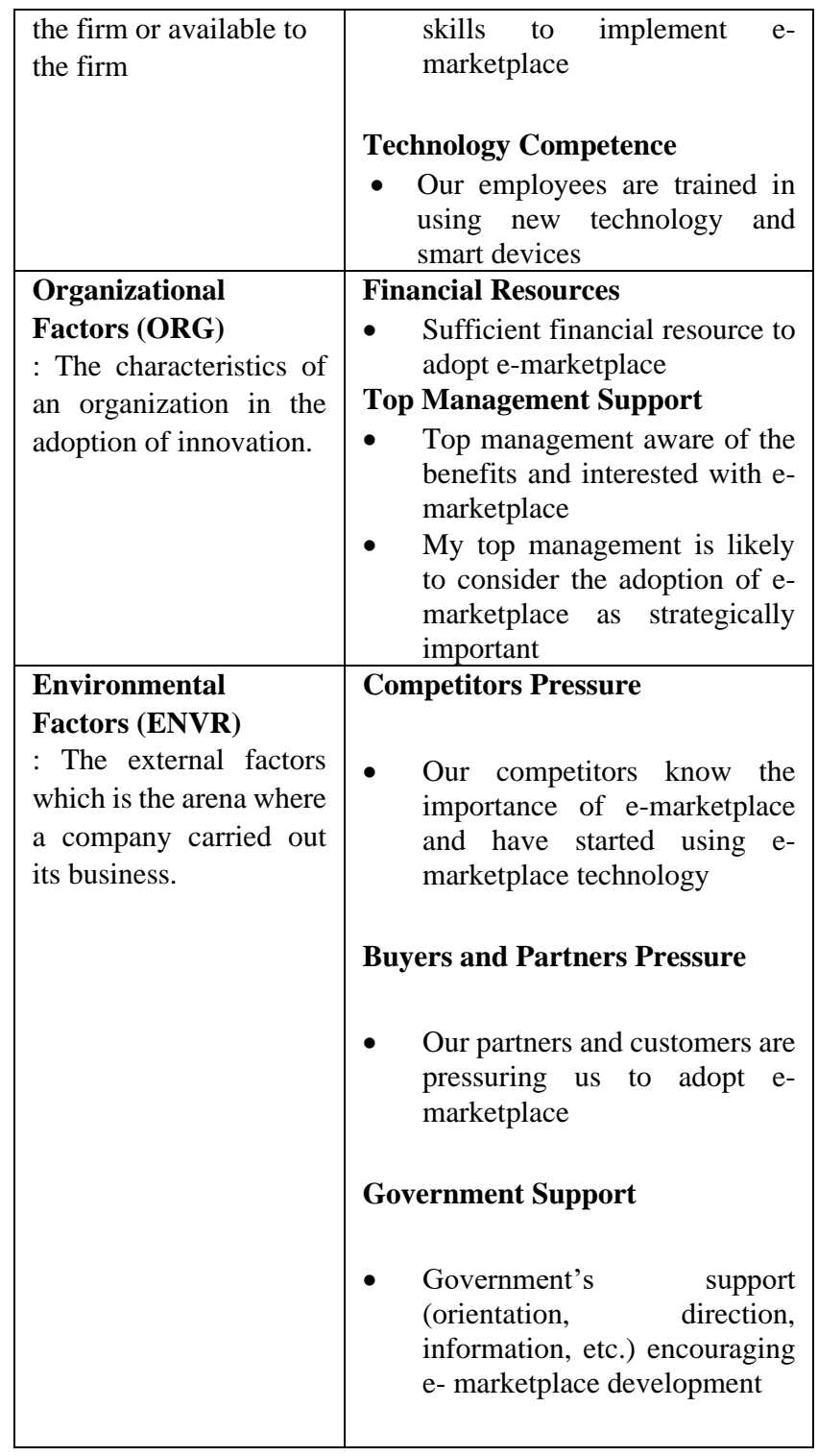

\section{RESULTS AND DISCUSSION}

\subsection{Demographic Statistics}

Figure 1 depicted the pie chart of the respondents' gender. 55.0\% of the respondents were male. This indicated that most of the entrepreneurs utilizing e-marketplace within these 3 regencies are dominated by male.
EBIMCS 2019, December, 2019, Kuala Lumpur, Malaysia

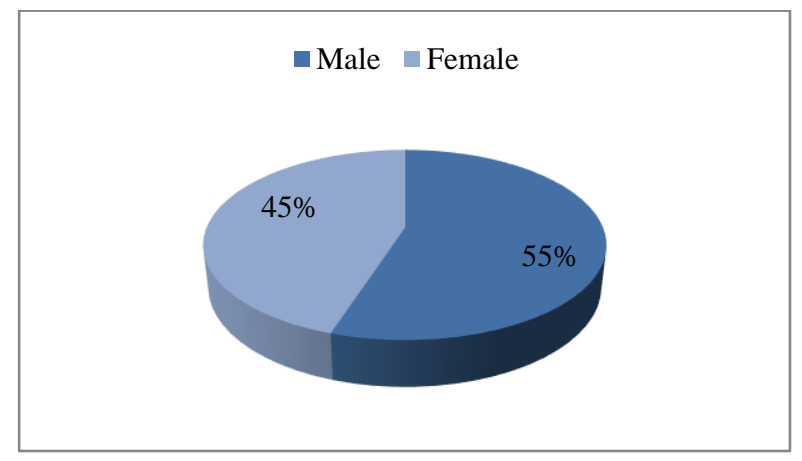

Figure 1. Respondents' gender

The data in Table 3 tabulated the breakdown of the respondents' age into four groups which are 20 years old and below, 21 to 30 years old, 31 to 40 years old, and 41 years and above. Comparing these age groups, the highest number of entrepreneurs is within the age group of 21-30 years old with 58 respondents. This is followed by 24 respondents who are 20 years old and below. The remaining respondents are in the age range of 31-40 years old. No respondents in this study are reported to be 41 years and above.

Table 3. Respondents' age

\begin{tabular}{|l|c|c|}
\hline Age & Number of Respondents & Percentage \\
\hline$\leq 20$ & 24 & $24.0 \%$ \\
\hline $21-30$ & 58 & $58.0 \%$ \\
\hline $31-40$ & 18 & $18.0 \%$ \\
\hline$\geq 41$ & 0 & $0 \%$ \\
\hline Total & 100 & $100 \%$ \\
\hline
\end{tabular}

The respondents' years of experience as entrepreneur are presented in the Figure 2. With reference to the bar graph, $48.0 \%$ of the respondents which is the majority had working experience of 2 to 3 years. Only 1 respondent had a working experience of 7 to 9 years while the rest had less than 1 year (17 respondents), and 4 to 6 years (34 respondents).

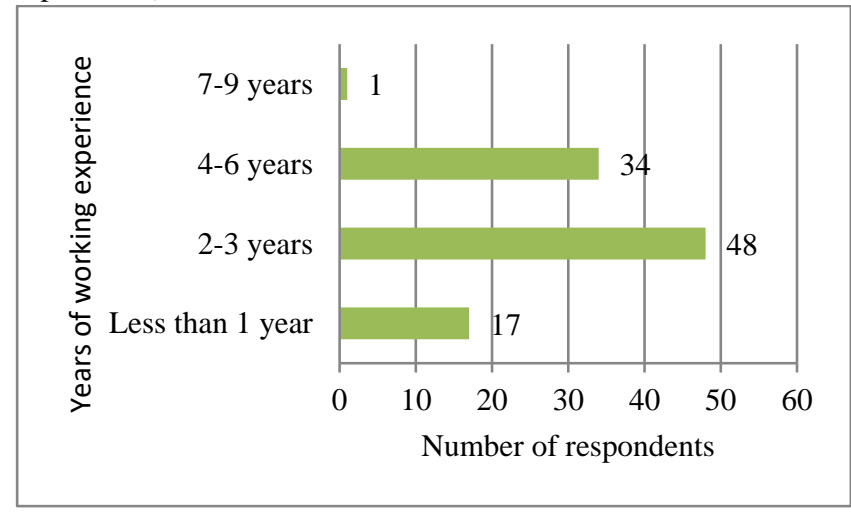

Figure 2. Respondents' working experience

\subsection{Descriptive Statistic}

he results of the descriptive statistical test are shown in Table 4. The information obtained from this test included the number of 
observations, minimum values, maximum values, average values, and standard deviations.

The technological factors construct data is obtained from distributing questionnaires online with 3 items with the use of a 5point Likert Scale, having a theoretical score between the lowest score of 3 to the highest score of 15 . The empirical score on the emarketplace adoption model spreads from the lowest score of 8 to the highest score of 15 , with a total score of 1185 , mean 11.85 and standard deviation of 1.598 .

The organizational factors construct data was obtained from distributing questionnaires online with the number of questions as many as 3 items with the use of a 5-point Likert Scale, having a theoretical score between the lowest score of 3 to the highest score of 15 . The empirical score on the e- marketplace adoption model spreads from the lowest score of 8 to the highest score of 15 , with a total score of 1182, mean 11.82 and standard deviation of 1.749 .

The environmental factors construct data was obtained from distributing questionnaires online with the number of questions as many as 3 items by using a 5-point Likert Scale, having a theoretical score between the lowest score 3 to the highest score of 15. The empirical score on the e- marketplace adoption model spreads from the lowest score of 7 to the highest score of 15, with a total score of 1155, mean 11.55 and standard deviation of 2.066.

Table 4. Descriptive statistical test result of the variables

\begin{tabular}{|l|c|c|c|c|c|c|}
\hline \multicolumn{2}{|c|}{ N } & Minimum & Maximum & Sum & Mean & $\begin{array}{c}\text { Std. } \\
\text { Deviation }\end{array}$ \\
\hline $\begin{array}{l}\text { Technological } \\
\text { Factors } \\
\text { (TECH) }\end{array}$ & 100 & 8 & 15 & 1185 & 11.85 & 1.598 \\
\hline $\begin{array}{l}\text { Organizational } \\
\text { Factors (ORG) }\end{array}$ & 100 & 8 & 15 & 1182 & 11.82 & 1.749 \\
\hline $\begin{array}{l}\text { Environmental } \\
\text { Factors } \\
\text { (ENVR) }\end{array}$ & 100 & 7 & 15 & 1155 & 11.55 & 2.066 \\
\hline
\end{tabular}

\subsection{Model Evaluation}

\subsubsection{Convergent Validity}

Convergent validity, a measurement model with reflexive indicators is assessed based on the correlation between items scores calculated by PLS. Test of convergent validity in PLS with reflective indicators is assessed based on loading factors (correlation between item scores / component scores with construct scores) indicators that measure the construct [12].

With reference to the output loading (refer Table 5), it was found that the results of the loading factor of all the indicators of each construct have fulfilled the convergent validity since the loading factor value of each indicator has shown a value greater than the recommended which is 0.6 . Thus, it can be said that the indicators used in this study are valid or have fulfilled the convergence validity.
Table 5. Output for loading factors

\begin{tabular}{|c|c|c|c|c|}
\hline & BI & ENVR & ORG & TECH \\
\hline BI1 & 0.838 & & & \\
\hline BI2 & 0.698 & & & \\
\hline ENVR1 & & 0.873 & & \\
\hline ENVR2 & & 0.884 & & \\
\hline ENVR3 & & 0.711 & & \\
\hline ORG1 & & & 0.839 & \\
\hline ORG2 & & & 0.831 & \\
\hline ORG3 & & & 0.789 & \\
\hline TECH1 & & & & 0.897 \\
\hline TECH2 & & & & 0.808 \\
\hline TECH3 & & & & 0.666 \\
\hline
\end{tabular}

Note : BI - behavioral intention, ENVR-environmental factor, ORG-organizational factor, TECH- technological factor

3.3.2 Average Variance Extracted (AVE)

Another method of validity testing is by referring to the value of Average Variance Extracted (AVE). An AVE value greater than 0.5 indicates the variable is valid. The outputs of AVE on the adoption model of e-marketplace are tabulated in Table 6 . Performance expectancy, task technology fit, and behavioral intention have AVE values greater than 0.5 which means that the indicator used in this study are valid or have fulfilled the convergence validity.

Table 6. E-marketplace adoption model AVE results

\begin{tabular}{|l|c|}
\hline \multicolumn{1}{|c|}{ Construct } & \multicolumn{1}{|c|}{$\begin{array}{c}\text { Average Variance } \\
\text { Extracted (AVE) }\end{array}$} \\
\hline Technology Factors (TECH) & 0.633 \\
\hline Organization Factors (ORG) & 0.672 \\
\hline $\begin{array}{l}\text { Environmental Factors } \\
\text { (ENVR) }\end{array}$ & 0.683 \\
\hline Behavior Intention (BI) & 0.661 \\
\hline
\end{tabular}

\subsection{Hypothesis Testing}

The bootstrapping results of the three variables towards behavioral intention (BI) are shown in Table 7.

The relationship between TECH and BI showed a negative insignificant effect on e-marketplace adoption ( $\mathrm{p}>0.05$, t-statistic $=0.004<1.960$ ). Thus, hypothesis 1 is rejected. The insignificant result between these variables is consistent with past literature [1314]. TECH factors in this paper are related to the availability of ICT and internet, ICT competence of the employee, and the availability of ICT training for the employee. In this context, some MSMEs might do not have proper ICT infrastructure in conducting emarketplace. Even if MSMEs have sophisticated ICT in the organization, the lack of skills and knowledge of employees are still becoming the challenge in the MSMEs to utilize e-marketplace in 
business activities. In addition, given that MSMEs are businesses that have minimal capital, ICT training for employees is rarely done. The path between ORG and BI in this research showed a positive and significant influence on e-marketplace adoption $(\mathrm{p}<0.05, \mathrm{t}$ statistic $=2.062>1.960)$ which also proved that second hypothesis is supported. This finding is in accordance with the other research [15-17]. Without sufficient financial resources and support from top management, MSMEs are unable to adopt the new system especially e-marketplace.

The association between ENVR and BI was significant and positive on e-marketplace adoption $(\mathrm{p}<0.05$, $\mathrm{t}$-statistic $=2.587>$ 1.960). In other words, the third hypothesis is accepted. The result is consistent with previous study [2,5,18-19] which showed that external pressure was an important factor that positively influencing the acceptance of technologies in MSMEs. External pressure in this paper includes competitors, partners and customers, as well as the role of government. These three things have been proven in increasing MSMEs desire to adopt e-marketplaces to remain competitive and not be left behind by other competitors and want to meet the needs of their customers. Furthermore, currently the government in Indonesia also has one of the visions to improve e-commerce transactions by supporting MSMEs to join emarketplaces in Indonesia and together can improve the nation's economy.

Table 7. E-marketplace model adoption bootstrapping results

\begin{tabular}{|l|c|c|c|}
\hline & $\begin{array}{c}\text { Original Sample } \\
(\mathbf{O})\end{array}$ & $\begin{array}{c}\text { T Statistics } \\
(\mid \mathbf{O} / \text { STDEV } \mid)\end{array}$ & $\begin{array}{c}\mathbf{P} \\
\text { Values }\end{array}$ \\
\hline TECH -> BI & -0.004 & 0.043 & 0.966 \\
\hline ORG -> BI & 0.191 & 2.062 & 0.042 \\
\hline ENVR -> BI & 0.216 & 2.587 & 0.011 \\
\hline
\end{tabular}

Note : BI - behavioral intention, ENVR-environmental factor, ORG-organizational factor, TECH- technological factor

\section{CONCLUSION}

Based on the findings ( $\mathrm{p}$-values and t-statistics) from this study, it can be concluded that organizational factors and environmental factors have positive significant impact on the adoption of emarketplace whereas technological factors appeared not to have any influence. Considering environmental factors have a positive and significant effect on the acceptance and use of e-marketplaces in MSMEs, it is recommended that government to be more focused on the adoption of e- marketplaces in the MSMEs for their development by implementing policies and programs.

\section{REFERENCES}

[1] Ghobakhloo, M., Hong, T. S., \& Standing, C. 2015. B2B E-commerce success among small and medium-sized enterprises: a business network perspective. Journal of Organizational and End User Computing (JOEUC), 27(1), 1-32.

[2] Duan, X., Deng, H., \& Corbitt, B. 2012. Evaluating the critical determinants for adopting e-market in Australian small-and-medium sized enterprises. Management Research Review, 35(3/4), 289-308.

[3] Awa, H. O., Ukoha, O., \& Emecheta, B. C. 2016. Using TOE theoretical framework to study the adoption of ERP solution. Cogent Business \& Management, 3(1), 1196571.

[4] Pool, J. K., Arabzad, S. M., Asadi, A., \& Ansari, M. R. 2015. RFID acceptance in SMEs using TOE framework: an empirical investigation on Iranian SMEs. International Journal of Logistics Systems and Management, 21(3), 335-347.

[5] Gangwar, H., Date, H., \& Ramaswamy, R. 2015. Understanding determinants of cloud computing adoption using an integrated TAM-TOE model. Journal of Enterprise Information Management, 28(1), 107-130.

[6] Kabanda, S., \& Brown, I. 2017. A structuration analysis of Small and Medium Enterprise (SME) adoption of E-Commerce: The case of Tanzania. Telematics and Informatics, 34(4), 118-132.

[7] Abdullah, A. 2019. E-Business Adoption in Yemeni SMEs. (Unpublished doctoral dissertation). University of South Wales / Prifysgol De Cymru.

[8] Aboelmaged, M. 2018. The drivers of sustainable manufacturing practices in Egyptian SMEs and their impact on competitive capabilities: A PLS-SEM model. Journal of Cleaner Production, 175, 207-221.

[9] Walker, J. H., Saffu, K., \& Mazurek, M. 2016. An empirical study of factors influencing e-commerce adoption/non-adoption in Slovakian SMEs. Journal of Internet Commerce, 15(3), 189-213.

[10] Thong, J. Y., \& Yap, C. S. 1995. CEO characteristics, organizational characteristics and information technology adoption in small businesses. Omega, 23(4), 429-442.

[11] Sanchez-Torres, J. A., \& Juarez-Acosta, F. 2019. Modelling SME e-commerce with IMAES. Journal of Business \& Industrial Marketing, 34(1), 137-149.

[12] Abdillah, W., \& Hartono, J. 2015. Partial Least Square (PLS): alternatif structura equation modeling (SEM) dalam penelitian bisnis. Yogyakarta: Penerbit Andi.

[13] Ifinedo, P. 2012. Internet/E-Business technologies acceptance in Canada's SMEs: Focus on organizational and environmental factors. In E-Business-Applications and Global Acceptance. IntechOpen.

[14] Ocloo, C. E., Xuhua, H., Akaba, S., Addai, M., Worwui-Brown, D., \& SpioKwofie, A. 2018. B2B E-commerce Adoption amongst manufacturing SMEs: Evidence from Ghana. Australian Journal of Economics and Management Sciences, 8(1), 126-146.

[15] Cruz-Jesus, F., Pinheiro, A., \& Oliveira, T. 2019. Understanding CRM adoption stages: empirical analysis building on the TOE framework. Computers in Industry, 109, 1-13.

[16] Kandil, A. M. N. A., Ragheb, M. A., Ragab, A. A., \& Farouk, M. 2018. Examining the effect of TOE model on cloud computing adoption in Egypt. The Business \& Management Review, 9(4), 113-123.

[17] Abu Bakar, A. R., Ahmad, S. Z., \& Ahmad, N. 2019. SME social media use: A study of predictive factors in the United Arab Emirates. Global Business and Organizational Excellence, 38(5), 53-68.

[18] Ghobakhloo, M., Arias-Aranda, D., \& Benitez-Amado, J. 2011. Adoption of ecommerce applications in SMEs. Industrial Management \& Data Systems, $111(8), 1238-1269$

[19] Usman, U. M. Z., Ahmad, M. N., \& Zakaria, N. H. 2019. The Determinants of Adoption of Cloud-Based ERP of Nigerian's SMES Manufacturing Sector Using Toe Framework and Doi Theory. International Journal of Enterprise Information Systems (IJEIS), 15(3), 27-43. 